\begin{tabular}{c|c|c}
\hline \hline $\begin{array}{c}\text { Vol. 31(4):283-296 } \\
\text { DOI: } 10.4217 / \text { OPR.2009.31.4.283 }\end{array}$ & Ocean and Polar Research & December 2009 \\
\hline \hline
\end{tabular}

\title{
Article
}

\section{Characteristics of a Warm Eddy Observed in the Ulleung Basin in July 2005}

\author{
Chang-Woong Shin ${ }^{*}$ \\ Climate Change \& Coastal Disaster Research Department, KORDI \\ Ansan P.O. Box, 29, Seoul 425-600, Korea
}

\begin{abstract}
Oceanographic survey data were analyzed to understand the characteristics of a warm eddy observed in the Ulleung Basin in July 2005. The temperature distribution at $200 \mathrm{db}$ and vertical sections provided evidence of the warm eddy in the Ulleung Basin (UWE05). Based on the $5^{\circ} \mathrm{C}$ isothermal line on $200 \mathrm{db}$ temperature, the major axis was $160 \mathrm{~km}$ from southwest to northeast, and the minor axis was $80 \mathrm{~km}$ from southeast to northwest. The homogeneous layer in the thermocline of UWE05 had mean values of $10.40^{\circ} \mathrm{C}$ potential temperature, $34.35 \mathrm{psu}$ salinity, and $26.37 \mathrm{~kg} / \mathrm{m}^{3}$ potential density $\left(\sigma_{\theta}\right)$ and provided evidence that UWE05 also existed during the winter of 2004-2005. A warm streamer initially flowed along the circumference of UWE05 and mixed with the upper central water. Two northward current cores were found on the western side of the measured current section at the central latitude of UWE05. One was the East Korean Warm Current (EKWC) and the other was the main stream of the western part of UWE05. Geostrophic transport of the upper layer (from the surface to the isopycnal surface of $26.9 \sigma_{\theta}$ ) was approximately $2.5 \mathrm{~Sv}$ in the eastern side of UWE05. However, the measured transport was twice as large as the geostrophic transport. Mass conservation of geostrophic transport was well satisfied in the upper layer. The direct current measurements and geostrophic transport analysis showed that the EKWC meandered around UWE05.
\end{abstract}

Key words : homogeneous layer, meandering, Ulleung warm eddy, volume transport, warm streamer

\section{Introduction}

The East Sea (Japan Sea) is enclosed by Korea, Russia, and Japan and is connected through four straits (Korea, Tsugaru, Soya, and Tartar) to the northwest Pacific (Fig. 1). Three large basins divide the bottom topography of the East Sea. The deepest is the Japan Basin, located in the northern East Sea. The other two basins, the Yamato and Ulleung basins, are located in the southern part of the East Sea. The Tsushima Warm Current (TWC) flows into the southern East Sea through the Korea Strait. It then branches into the East Korean Warm Current (EKWC) that flows northward along the east coast of Korea and the Nearshore Branch (NB) that flows eastward along the Japanese coast. In the northern East Sea, the Liman Current (LC) and the North Korea Cold Current (NKCC)

\footnotetext{
*Corresponding author. E-mail : cwshin@kordi.re.kr
}

flow southward along the coasts of Russia and northern Korea (Fig. 1). The EKWC and NKCC meet around 38$40^{\circ} \mathrm{N}$ and form the sub-polar front that flows out through the Tsugaru and Soya straits. Water masses south of the sub-polar front are vertically divided into four layers: seasonally varying surface water, the Tsushima Warm Current Water (TWCW) with high temperature $\left(\mathrm{T}>15^{\circ} \mathrm{C}\right)$ and high salinity $(\mathrm{S}>34.4 \mathrm{psu})$, the East Sea Intermediate Water (ESIW), characterized by the salinity minimum layer, and the nearly homogenous East Sea Proper Water (ESPW).

Mesoscale warm eddies exist in all three basins of the East Sea (Morimoto et al. 2000; Lee and Niiler 2005). A number of explanations have been given for the formation of the warm eddy in the Ulleung Basin (Ulleung Warm Eddy: UWE). One explanation involves meandering of the EKWC (Kim et al. 1997). Arruda et al. (2004) proposed that when the EKWC is strong, a beta effect and 


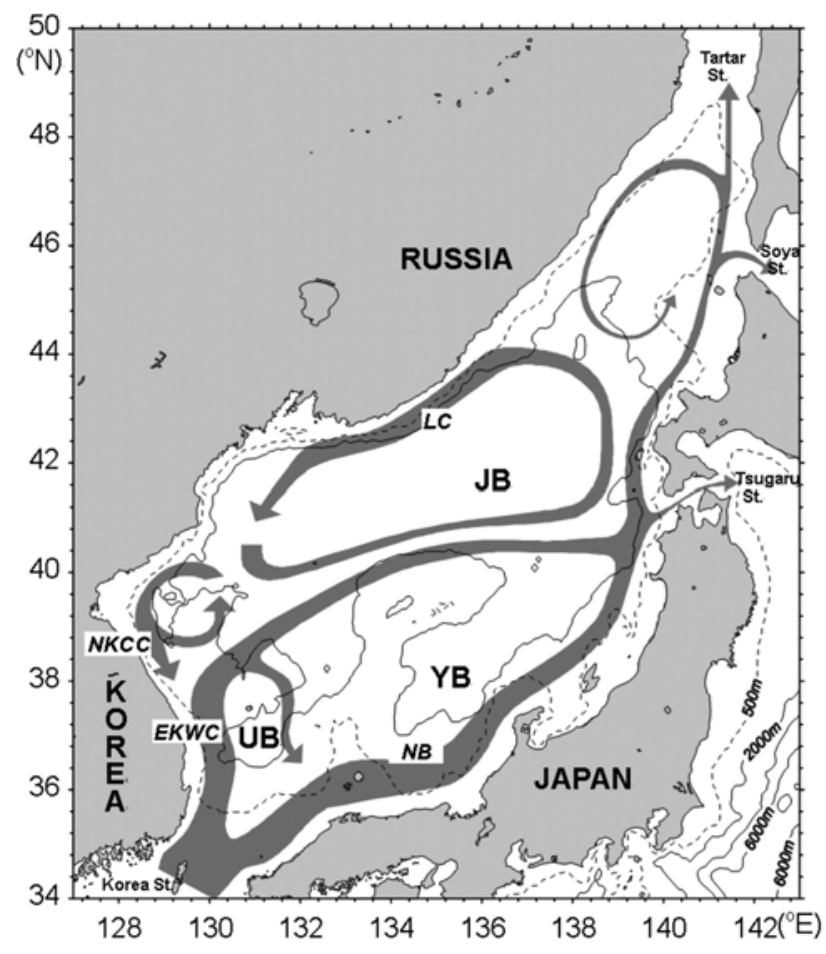

Fig. 1. Schematic diagram of the main surface currents and bottom topography of the East Sea. EKWC: East Korean Warm Current, NB: Nearshore Branch, NKCC: North Korean Cold Current, LC: Liman Current, UB: Ulleung Basin, YB: Yamato Basin, JB: Japan Basin (after Shin et al. 2005).

non-linearity lead to formation of the eddy. Bottom topography of the Ulleung Basin also affects the UWE (Seung et al. 1990; Lim and Kim 1995; Lie et al. 1995). An et al. (1994) statistically analyzed the shape of the UWE, showing it to be mainly elliptical with an average horizontal scale of $130 \mathrm{~km}$.

The UWE has mainly been observed in August, with a few other observations obtained in June. In a study by Lie et al. (1995), the UWE was observed from January 1992 to September 1993 by a satellite-tracked drifter buoy; in that case, the horizontal scales of the major and minor axes were 120 and $70 \mathrm{~km}$, respectively, the revolution period was 13.6 days, and the speed was $24 \mathrm{~cm} / \mathrm{s}$. A water mass of homogeneous temperature and salinity occurs at the center of the UWE between depths of 100 and $300 \mathrm{~m}$. This mass has a convex lens shape, and it is therefore often called the Ulleung Warm Lens (Cho et al. 1990; Kang and Kang 1990). The UWE persists for several months and moves northward along the east coast of Korea (Isoda and Saitoh 1993; Shin et al. 2005).

Although the UWE is formed by the EKWC, the UWE may have a reverse effect on the flow path of the EKWC (Seung 2002; Jacobs et al. 1999). The UWE also plays an important role in the ecosystems of the Ulleung Basin (e.g., Kang et al. 2004).

Many previous studies have advanced our understanding of the characteristics and formation dynamics of the UWE. However, few quantitative studies of the UWE have been conducted. The aim of this study was to quantitatively analyze the UWE observed in July 2005. The structure, physical properties, and evolution process of the eddy are first described and then analyzed quantitatively by calculating the geostrophic transport of the UWE.

\section{Data and method}

Characteristics of a warm eddy in the Ulleung Basin were revealed by analysis of oceanographic data surveyed by the R/V Eardo from 19 to 31 July 2005 (Fig. 2). Temperature and salinity were measured by conductivitytemperature-depth (CTD) (SEB 911plus) profilers, and water velocity was measured by a ship-mounted acoustic Doppler current profiler (ADCP, $150 \mathrm{kHz}, \mathrm{RDI}$ ). Measurements were taken along four survey lines including 34 stations from $36.0^{\circ} \mathrm{N}$ to $37.5^{\circ} \mathrm{N}$ at $0.5^{\circ} \mathrm{N}$ intervals.

Vertical profiles of velocity were measured from 12 to $284 \mathrm{~m}$ at 8-m intervals every 1 minute for an ensemble average. To calculate absolute velocities, tracking modes were selected as follows. If the bottom depth was shallower than $350 \mathrm{~m}$, a bottom-tracking mode was selected. If the bottom depth was deeper than $350 \mathrm{~m}$, the tracking mode was changed automatically to a navigation mode. To increase confidence in the analyzed data, poor quality data were excluded or averaged based on certain conditions. For example, data observed during a change of more than $30^{\circ}$ per minute in the ship's heading were excluded because the turning movement of the ship could cause errors in water velocity measurements. Extraordinary data indicating velocities greater than $150 \mathrm{~cm} / \mathrm{s}$ or variation in surface velocity direction greater than $90^{\circ}$ compared to the former ensemble were also excluded. The selected and filtered data were averaged using a 20-minute moving average. If fewer than 10 data points were obtained, those averaged data were omitted in the time average. An average was then calculated for each $\pm 0.1^{\circ} \mathrm{N}, \pm 0.1^{\circ} \mathrm{E}$ box for data numbers greater than 3 .

Temperature and salinity were processed using standard methods and averaged every $1 \mathrm{~m}$ depth. Because the CTD sensors had been calibrated by the manufacturer in May 


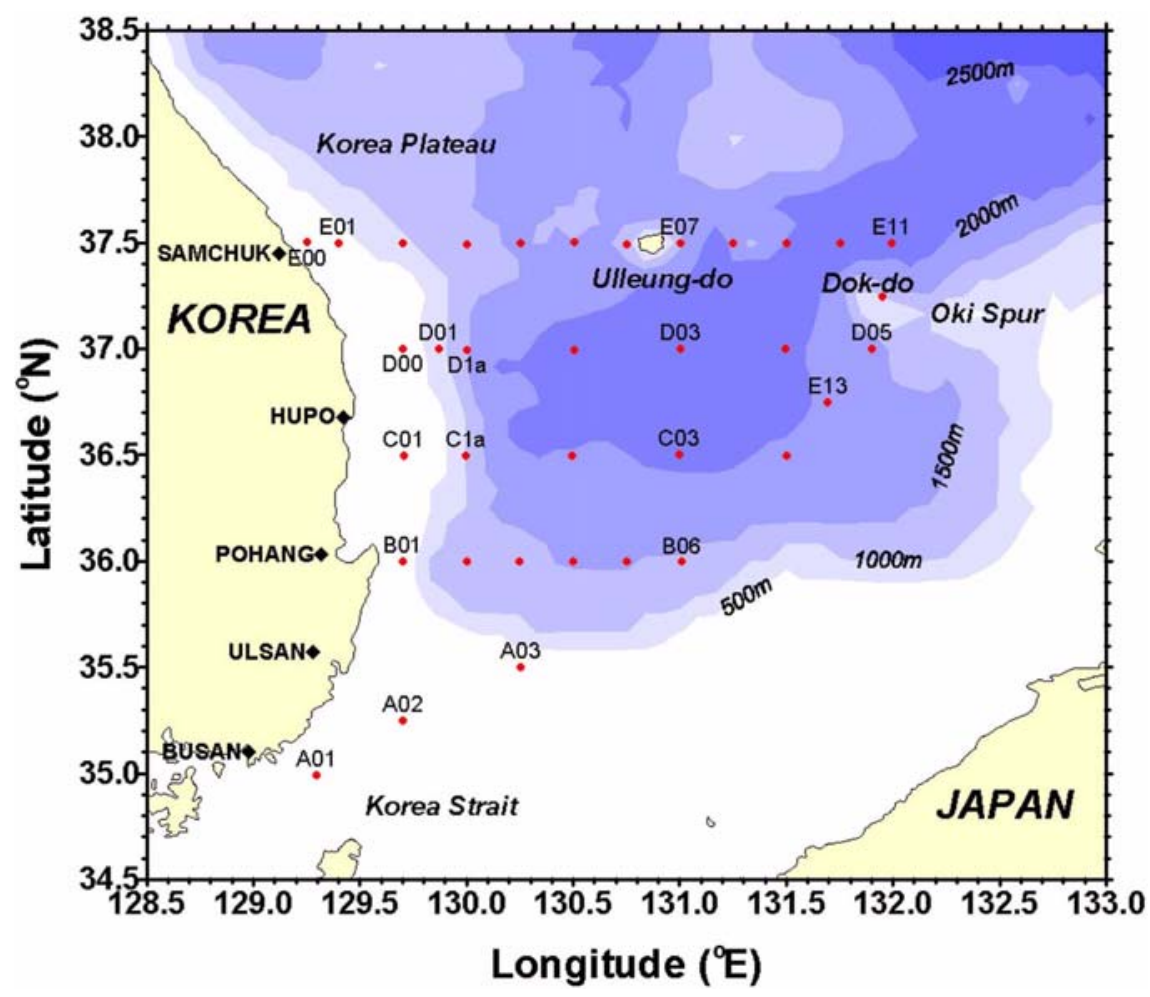

Fig. 2. Station map with bottom topography.

2005, no further calibration was conducted. For comparison with measured current speed, the dynamic height and geostrophic current were calculated from the CTD data. In this calculation, the bottom depth of the deepest station was regarded as the reference layer. For stations shallower than the reference depth, the dynamic depths were extrapolated based on the vertical gradient to the nearest station (Shin et al. 1996). Bimonthly serial oceanographic data observed by the National Fisheries Research and Development Institute (NFRDI) in the Ulleung Basin before and after July 2005 were analyzed.

\section{Results}

\section{Structure of UWE05}

Fig. 3 presents horizontal distributions of temperature and salinity observed from 19 to 31 July 2005 . Near the surface $(10 \mathrm{db})$, water below $19^{\circ} \mathrm{C}$ and colder than surrounding water extended from the middle part of eastern South Korea $\left(37.0^{\circ} \mathrm{N}, 129.5^{\circ} \mathrm{E}\right)$ to the Ulleung Basin. Salinity at the near surface $(10 \mathrm{db})$ was low (less than $34.0 \mathrm{psu}$ ) in the northern and southern parts of the survey area and relatively high from the central coast to the Ulleung Basin at $37.0^{\circ} \mathrm{N}, 129.5^{\circ} \mathrm{E}$, similar to the low temperature distribution.
On the other hand, a strong thermal front was found from Pohang to Ulleung-do (Ulleung Island) at $100 \mathrm{db}$. Cold water occupied the coastal side of the front, while water warmer than $10^{\circ} \mathrm{C}$ occupied the other side. Salinity at $100 \mathrm{db}$ was low $(\mathrm{S}<34.1)$ in the coastal side of the front, while high salinity water ( $\mathrm{S}>34.3 \mathrm{psu}$ ) was found on the other side. Warm water with temperature above $5^{\circ} \mathrm{C}$ at $200 \mathrm{db}$ was horizontally elongated from the southwest to northeast at the center of the Ulleung Basin. This warm water also had higher salinity (>34.15 psu) than the surrounding waters. The high salinity water at the center of the Ulleung Basin had an elliptical shape. Based on the $5^{\circ} \mathrm{C}$ isothermal line on $200 \mathrm{db}$ temperature, the major axis was $160 \mathrm{~km}$ from southwest to northeast, and the minor axis was $80 \mathrm{~km}$ from southeast to northwest. The major axis was two times longer than the minor axis.

Fig. 4 shows vertical sections of temperature and salinity along the south-north line (Line SN) and west-east line (Line WE) depicted in the horizontal distribution of temperature at $200 \mathrm{db}$ in Fig. 3. In the temperature section, a convex-lens-shaped isothermal layer is centered at station D03 between $10^{\circ} \mathrm{C}$ and $11^{\circ} \mathrm{C}$. The lens was 123 $\mathrm{m}$ thick at station D03. If we define the horizontal size of the lens based on the intersection of the $10^{\circ} \mathrm{C}$ isothermal 


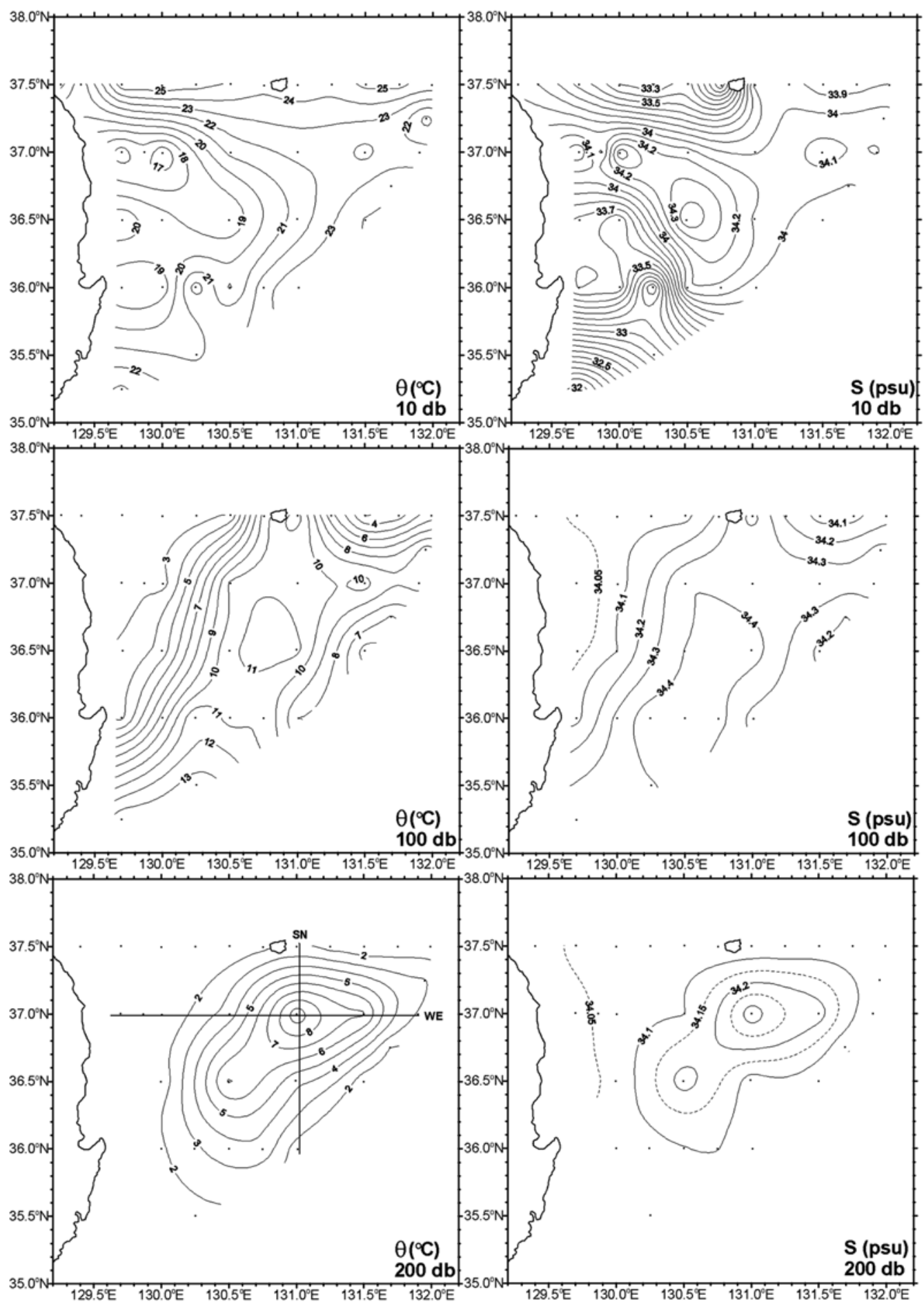

Fig. 3. Potential temperature $\left({ }^{\circ} \mathrm{C}\right)$ and salinity (psu) at three depths $(10,100,200 \mathrm{db})$ observed 19-31 July 2005 . In the potential temperature distribution at $200 \mathrm{db}$, two lines labeled SN and WE are shown that indicate vertical sections presented in the next figure.

line with $100 \mathrm{db}$ depth, then the lens was $100 \mathrm{~km}$ from east to west and $75 \mathrm{~km}$ from north to south. These horizontal and vertical distributions of temperature and salinity indicate the existence of a mesoscale warm eddy (called UWE05) in the Ulleung Basin. Temperature decreased with depth, while maximum and minimum salinity layers were found in upper and lower layer. Maximum salinity higher than 34.50 psu existed between 

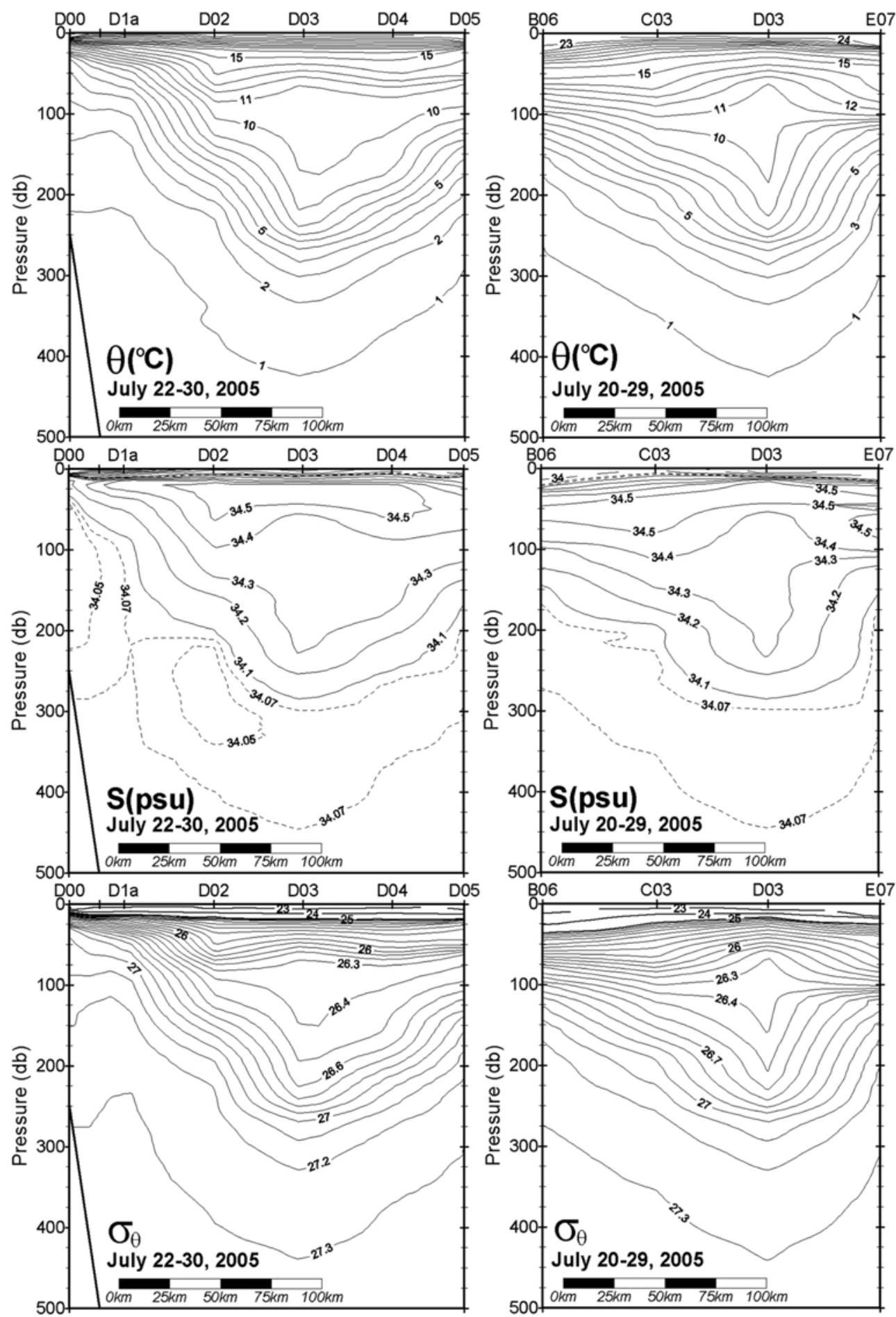

Fig. 4. Vertical sections of potential temperature $\left({ }^{\circ} \mathrm{C}\right)$, salinity (psu), and potential density $\left(\sigma_{\theta}, \mathrm{kg}^{-\mathrm{m}^{-3}}\right)$ along lines WE (from west to east, along $37^{\circ} \mathrm{N}$ ) and $\mathrm{SN}$ (from south to north, along $130^{\circ} \mathrm{E}$ ).

the low salinity surface layer and the isothermal layer. This high salinity water over the isothermal layer was advected from the warm streamer of UWE05.

The dynamic topography illustrated in Fig. 5 clearly shows the existence of UWE05 in the Ulleung Basin. At the surface, the EKWC flowed from the southeast coast of Korea to Ulleung-do and circulated in the Ulleung Basin. Although the flow speed at $200 \mathrm{db}$ depth was low compared with surface flow, clockwise circulation was continued in the Ulleung Basin. 


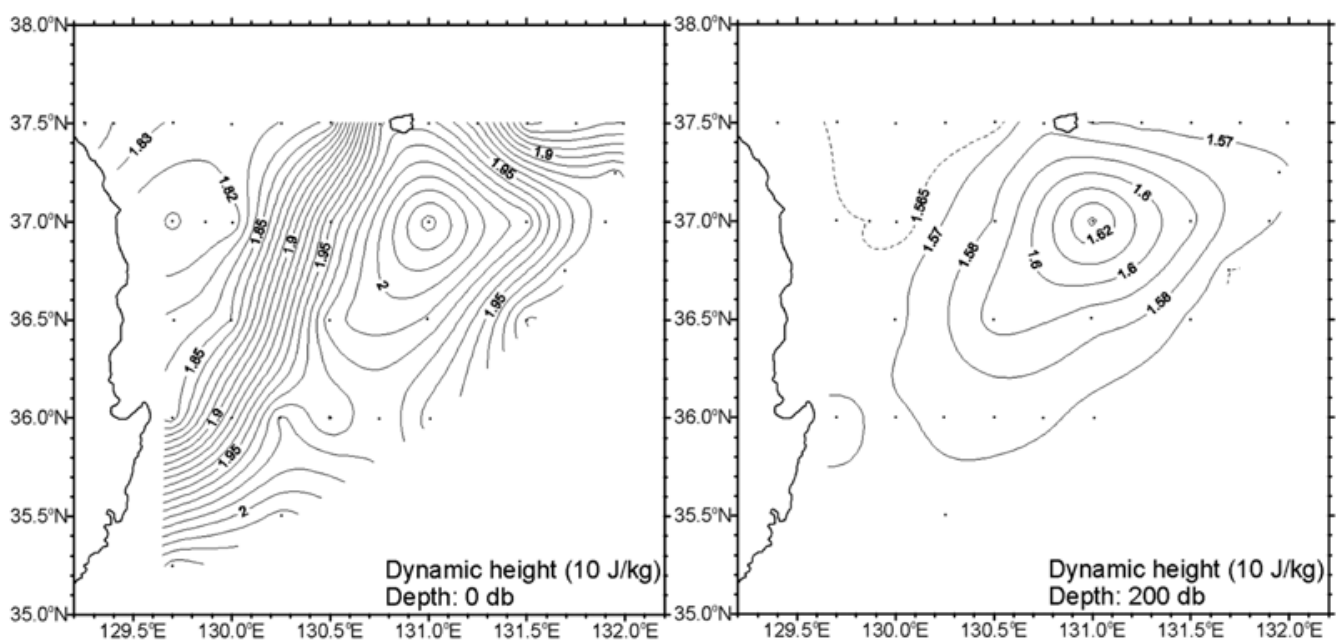

Fig. 5. Dynamic topography at the surface and at $200 \mathrm{db}$. The reference layer is $2379 \mathrm{db}$, which was the deepest observation depth. Dynamic depth for stations at which the bottom depth was shallower than the reference layer was extrapolated based on the vertical gradient of dynamic depth to the nearest station (Shin et al. 1996).

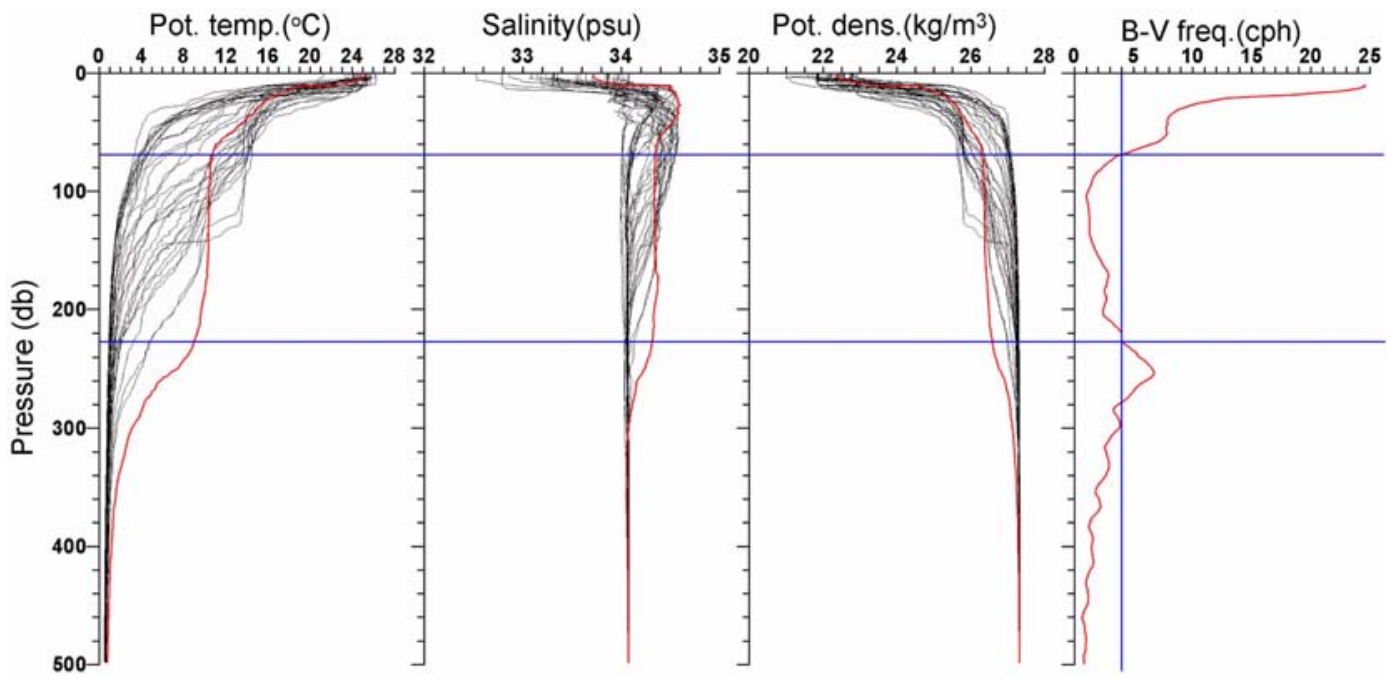

Fig. 6. Vertical profiles of potential temperature $\left({ }^{\circ} \mathrm{C}\right)$, salinity (psu), and potential density $\left(\sigma_{\theta}, \mathrm{kg} / \mathrm{m}^{3}\right)$ for all the observation stations and Brunt-Väisälä frequency (cph) at station D03. Red lines indicate profiles for station D03. The vertical blue line in the Brunt-Väisälä frequency profile indicates four cycles per hour. The two horizontal blue lines indicate depths of the local minimum of Brunt-Väisälä frequency, less than four cycles per hour between 69 and $226 \mathrm{~m}$ in depth.

\section{Variations of the warm lens and warm streamer}

The Brunt-Väisälä frequency is useful to describe stability and stratification. To investigate the water mass properties and stability of the lens-shaped homogeneous water at station D03, marking the center of the eddy, Fig. 6 presents temperature and salinity profiles for all observation data and Brunt-Väisälä frequency for station D03. Distinguishing the seasonal thermocline in the temperature profiles was difficult, except at station D03 and other stations near the center of the eddy. Between the seasonal and the permanent thermocline at station D03, the minimum Brunt-Väisälä frequency occurred in the homogeneous layer of temperature and salinity. The upper and lower levels at which the Brunt-Väisälä frequency was less than $4 \mathrm{cph}$ were $69 \mathrm{~m}$ and $226 \mathrm{~m}$, respectively. This homogeneous layer had mean values of $10.40^{\circ} \mathrm{C}$ potential temperature, $34.35 \mathrm{psu}$ salinity, and $26.37 \mathrm{~kg} / \mathrm{m}^{3}$ potential density $\left(\sigma_{\theta}\right)$. Thus, the center of the eddy was warmer, saltier, and less dense than peripheral water. The mean salinity of the homogeneous layer in the eddy was also approximately $0.1 \mathrm{psu}$ higher than that found in a previous observational study of the basin conducted in 


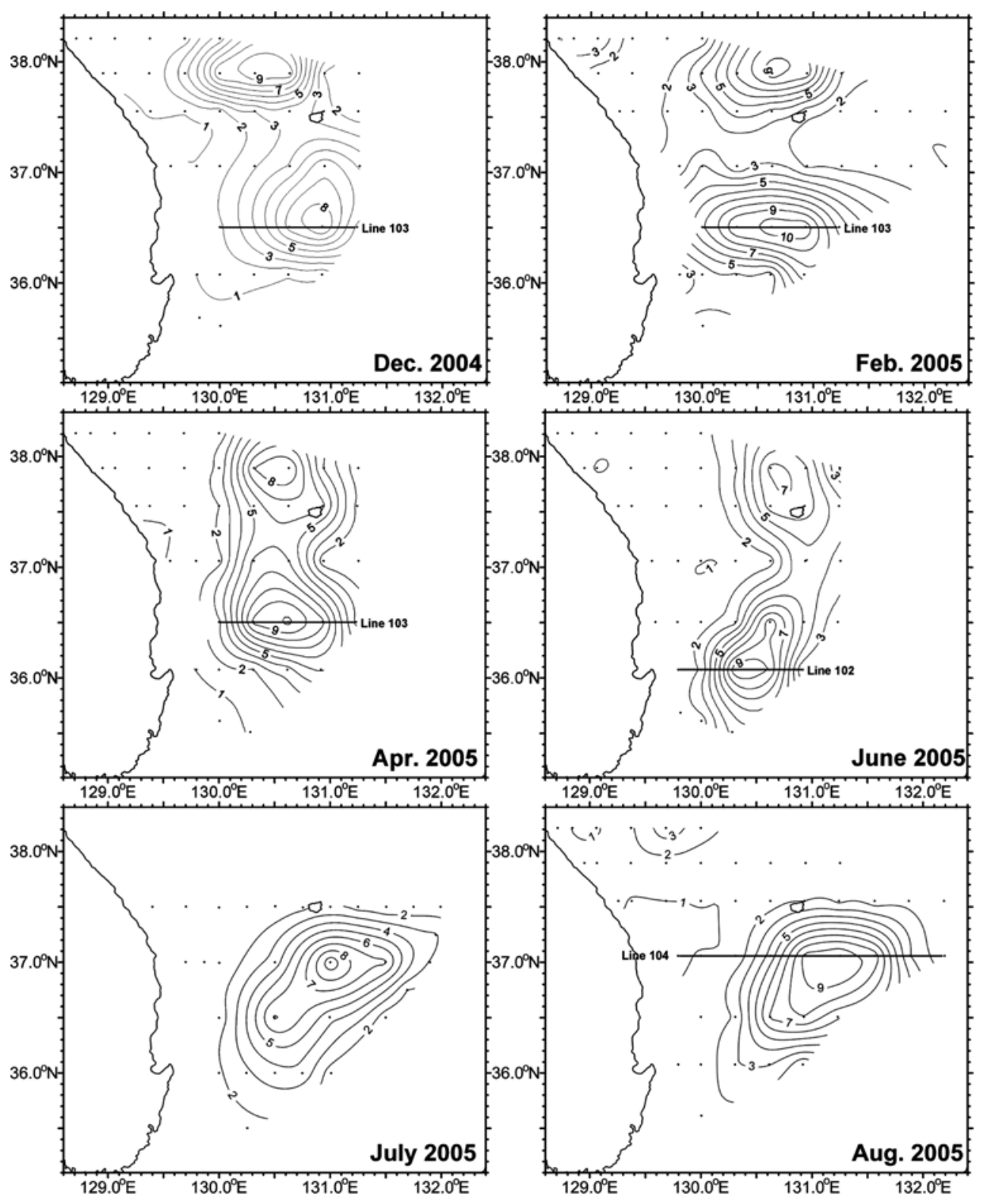

Fig. 7. Horizontal distribution of temperature at $200 \mathrm{~m}$ depth observed by NFRDI in December 2004 and February, April, June, and August 2005, including the distribution in July 2005. Vertical sections for Line 102 in June 2005, Line 103 in December 2004 and February and April 2005, and Line 104 in August 2005 are depicted in Fig. 8.

summer (Shin et al. 2005).

The existence of the homogeneous temperature and salinity layer in the middle of the thermocline suggests that UWE05 existed over the winter of 2004-2005, as found in former studies (e.g., Gordon et al. 2002; Shin et al. 2005). To examine the existence of UWE05 in the winter of 2004-2005 and its evolution after that winter, bimonthly serial oceanographic data observed by NFRDI were analyzed. Fig. 7 shows horizontal distributions of temperature at $200 \mathrm{~m}$ depth from December 2004 to
August 2005. In December 2004, two warm eddies were observed. One was in the Ulleung Basin (hereafter "basin eddy"), and the other was northwest of Ulleung-do (hereafter "northwest eddy"). The central temperatures were $8^{\circ} \mathrm{C}$ in the basin eddy and $9^{\circ} \mathrm{C}$ in the northwest eddy. After two months, in February 2005, the central temperature of the basin eddy had increased to $10^{\circ} \mathrm{C}$, but the temperature of the northwest eddy was unchanged. In April, the centers of the eddies were in the same positions, but a smaller area was occupied by water warmer than 


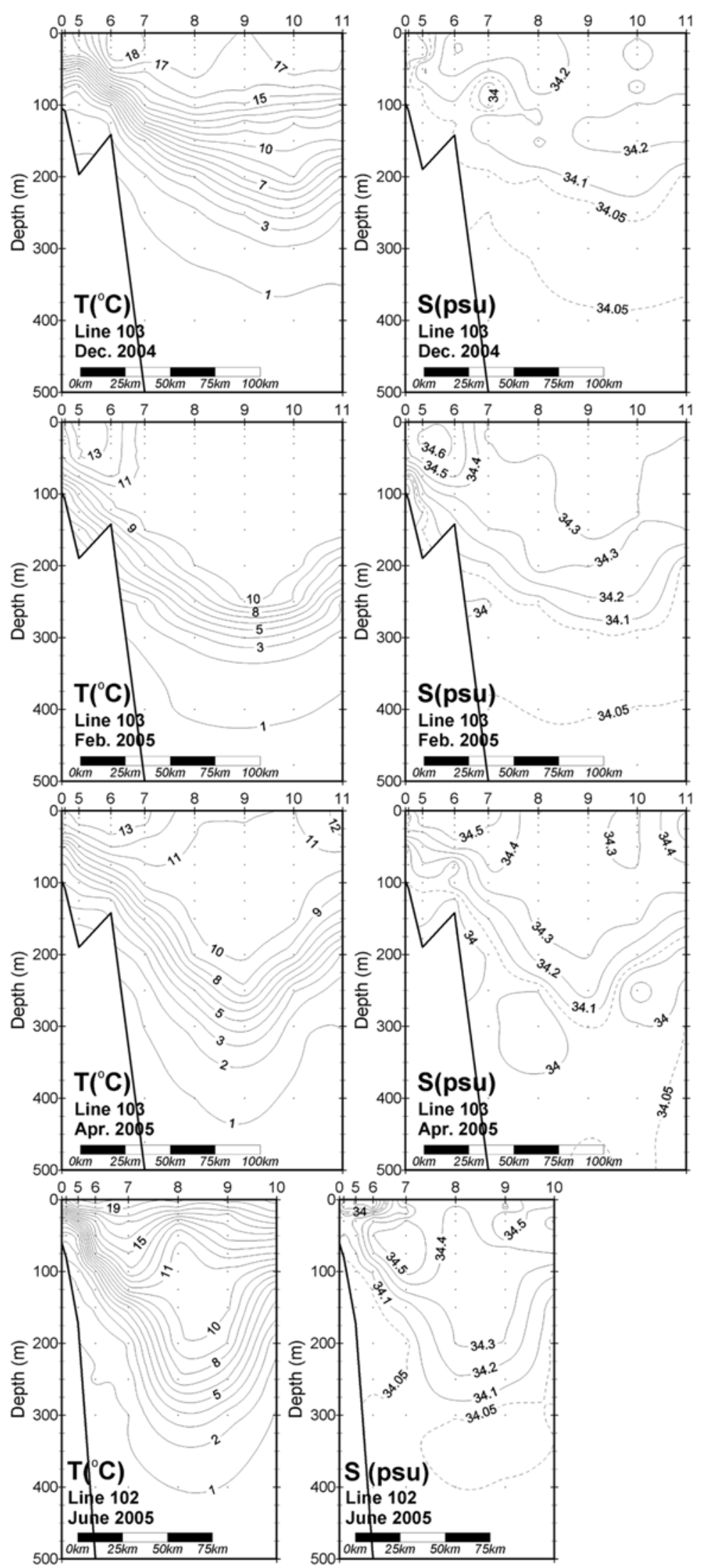

Fig. 8. Vertical zonal sections for temperature $\left({ }^{\circ} \mathrm{C}\right.$ ) and salinity (psu) across the warm eddy UWE05 (see Fig. 7). 

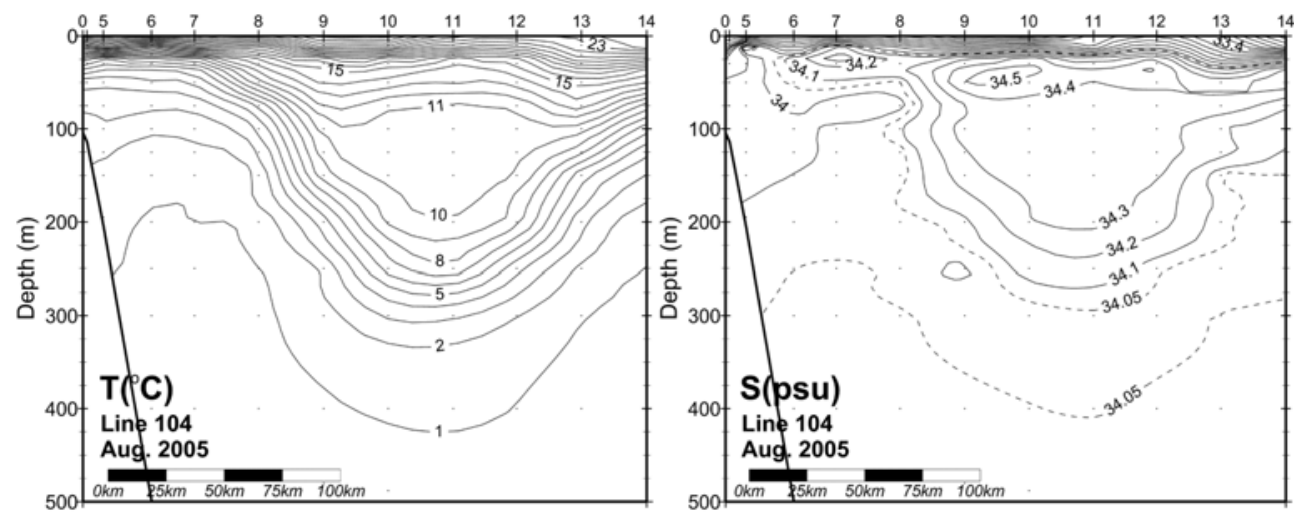

Fig. 8. Continued.

$10^{\circ} \mathrm{C}$ in the basin eddy, and the central temperature of the northwest eddy had decreased from $9^{\circ} \mathrm{C}$ to $8^{\circ} \mathrm{C}$. In June, the center of the basin eddy was at the same longitude but had shifted $0.5^{\circ}$ southward in latitude. The northwest eddy had moved approximately $0.1^{\circ}$ eastward from its location in April. The central temperatures of both eddies were approximately $1^{\circ} \mathrm{C}$ lower than in April. In August, the area occupied by the central eddy extended throughout the entire Ulleung Basin. The northwest eddy disappeared from the observation area in August.

Fig. 8 shows zonal vertical sections on the line transverse of the center of the basin eddy depicted in Fig. 7. In December 2004, a mixed layer was developing in the surface layer at the center of the eddy. In February 2005, a mixed layer, with temperatures of $10-11^{\circ} \mathrm{C}$ was developed by wind and convection from the surface to $250 \mathrm{~m}$ depth in the center of the eddy. Salinity was also homogeneous (34.2-34.3 psu) from the surface to $150 \mathrm{~m}$ depth. In western part of the eddy, high temperature $\left(>11^{\circ} \mathrm{C}\right)$ and high salinity (>34.4 psu) water was regarded as EKWC water.

In April, warm water covered the surface mixed layer that had developed in winter, and the lens-shaped homogeneous layer was forming. High temperature and high salinity water appeared at the western and eastern sides of the eddy, suggesting that the EKWC flowed along the side of eddy and formed a warm streamer. In June, the warm lens, which was homogeneous in temperature and salinity, was thinner than that observed in April. Salinity over the warm lens was also higher than that in April. This indicates that the warm saline streamer extended from the circumference to the center of the eddy surface. The high temperature and high salinity water covered the top of the homogeneous layer of the eddy in July and August. The horizontal distributions of temperature at 200 $\mathrm{m}$ depth and vertical sections of the eddy provided evidence that the eddy existed in the winter of 2004-2005 and that the basin eddy was UWE05.

Table 1 shows the evolution of the $10-11^{\circ} \mathrm{C}$ homogeneous layer of UWE05. The thickness of the homogeneous layer decreased with time from $251 \mathrm{~m}$ in February to $114 \mathrm{~m}$ in August because of a nonlinear effect of advection of the warm streamer in the upper layer into the upper eddy. From February to July 2005, the mean temperature of the homogeneous layer decreased, but the salinity increased. However, little change was observed in the water properties following the formation of the homogeneous layer in winter.

Table 1. Time variation of the mean temperature and salinity of the homogeneous temperature $\left(10-11^{\circ} \mathrm{C}\right)$ layer in the middle of UWE05 observed in 2005. $D_{11}$ and $D_{10}$ indicate the upper and lower depths of the homogeneous layer, respectively. Depth ranges in February, April, June, and August are not precise because the available NFRDI data were for standard depths

\begin{tabular}{cccccc}
\hline & Feb. & Apr. & Jun. & Jul. & Aug. \\
\hline $\mathrm{D}_{11}-\mathrm{D}_{10}(\mathrm{~m})$ & $0-251$ & $20-208$ & $58-178$ & $63-185$ & $73-187$ \\
$($ Thickness) & $(251)$ & $(188)$ & $(120)$ & $(122)$ & $(114)$ \\
Mean T. $\left({ }^{\circ} \mathrm{C}\right)$ & 10.70 & 10.49 & 10.41 & 10.40 & 10.41 \\
Mean S. (psu) & 34.28 & 34.32 & 34.33 & 34.35 & 34.32 \\
\hline
\end{tabular}




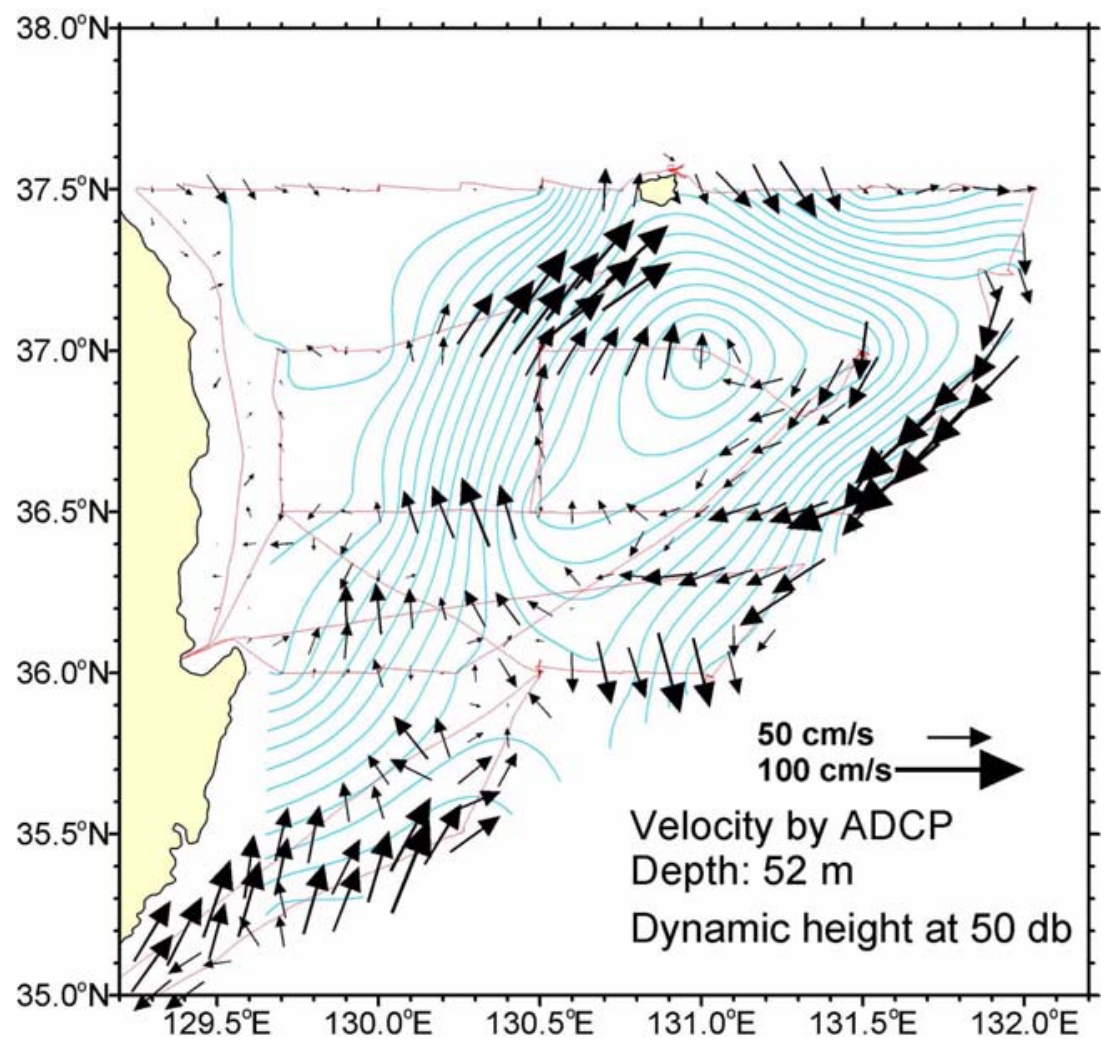

Fig. 9. Current velocity vectors measured by ship-mounted ADCP at $52 \mathrm{~m}$ depth during the cruise over the contour of dynamic height (light blue lines) at $50 \mathrm{db}$. Red lines indicate the ship's path.

\section{Currents and volume transports of UWE05}

Fig. 9 shows the surface current velocity vectors at $52 \mathrm{~m}$ depth observed by the ship-mounted ADCP with dynamic height at $50 \mathrm{db}$. The current vectors indicate that the UWE05 flowed anti-cyclonically and was consistent with the dynamic height in speed and direction. Current vectors along $37^{\circ} \mathrm{N}$ show that current direction changed around the area east of station D03. Thus, the center of UWE05 was between $131^{\circ} \mathrm{E}$ and $131.5^{\circ} \mathrm{E}$ in longitude. Horizontal speed was strong in eastern and western parts of the eddy and weak in southern and northern parts. In the southern part of the eddy (around $36.0^{\circ} \mathrm{N}, 131.0^{\circ} \mathrm{E}$ ), the current direction was southeastward rather than westward. Thus, a large part of the western water of the eddy did not recirculate, but instead flowed out to the southeast.

Vertical sections of meridional velocity measured by the ship-mounted ADCP (Va) and calculated dynamically $(\mathrm{Vg})$ are shown in Fig. 10 for the four observation lines depicted in Fig. 2. As a whole, the geostrophic currents were simpler and weaker than the measured currents because of the large distances between stations. At the $36.0^{\circ} \mathrm{N}$ section, the EKWC existed at $130^{\circ} \mathrm{E}$ with $75 \mathrm{~m}$ depth and 20-30 cm/s flow speed. This shallow EKWC resulted from TWC water passing through the Korea Strait. It seems that two northward current cores with velocities greater than $10 \mathrm{~cm} / \mathrm{s}$ existed in the measured current at the $36.0^{\circ} \mathrm{N}$ section. One was the EKWC; the other was located around $130.4-130.5^{\circ} \mathrm{E}$, east of the EKWC at $150 \mathrm{~m}$. East of $130.6^{\circ} \mathrm{E}$, the current speed was $40-60 \mathrm{~cm} / \mathrm{s}$ and flowed southward, with a core centered at $130.9^{\circ} \mathrm{E}$.

In the $36.5^{\circ} \mathrm{N}$ section, at the southern part of the UWE05, a northward current was observed at 129.9$130.8^{\circ} \mathrm{E}$, and a southward current east of $130.9^{\circ} \mathrm{E}$. Two current cores were also observed in the northward current area, as was found for the $36.0^{\circ} \mathrm{N}$ section. One was located at $130.2-103.3^{\circ} \mathrm{E}$, with current speed of $60-20 \mathrm{~cm} / \mathrm{s}$ at depths shallower than $100 \mathrm{~m}$, and the other was positioned around $130.7^{\circ} \mathrm{E}$, with current speed of $15-20$ $\mathrm{cm} / \mathrm{s}$ in depths of 50-200 m. The northward current core in the west seems to have been a warm streamer, whereas the eastern core may have been part of the recirculation of the eddy. However, the southward current area had only one current core.

In the transverse section of $37.0^{\circ} \mathrm{N}$, the central latitude 


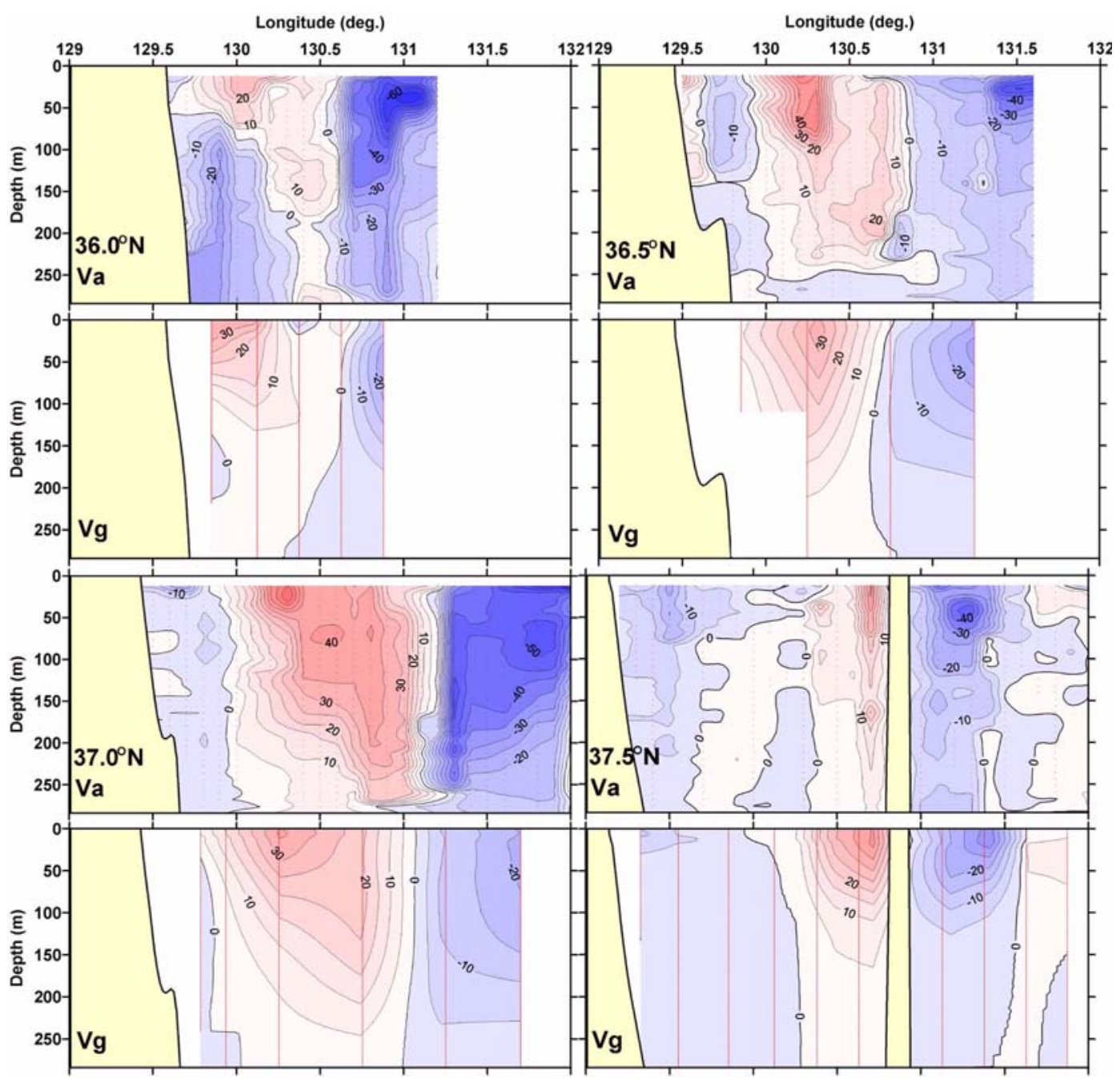

Fig. 10. Vertical sections of meridional velocity measured by the ship-mounted ADCP (Va) and calculated dynamically (Vg). Red and blue areas indicate northward and southward speeds, respectively. Red dots indicate data points.

of UWE05, the northward current was located at 130.0$131.1^{\circ} \mathrm{E}$, and the southward current was east of $131.2^{\circ} \mathrm{E}$. Two cores were identified in both the northward and southward current areas. The outer cores were shallower and faster than the inner cores. The outer cores were the warm streamers, and the inner cores represented the warm eddy.

In the section of $37.5^{\circ} \mathrm{N}$, it was difficult to distinguish two cores compared with the $37.0^{\circ} \mathrm{N}$ and $36.5^{\circ} \mathrm{N}$ sections. The current was northward west of Ulleung-do and southward on the other side of the island. The southward current occupied a wider area than did the northward current. Summarizing the above results, the EKWC flowed as a warm streamer and rotated around the eddy.

The currents calculated by the dynamical method were simpler and slower than the measured current speed.
Thus, the two northward current cores and subsurface maximum current were not shown in the geostrophic current section.

In the southern East Sea, water masses can be vertically divided into four layers: the surface layer with TWC water, the ESIW, the upper portion of ESPW, and the lower portion of ESPW (Shin et al. 1999). The potential densities $\left(\sigma_{t}\right)$ that divide each layer are 26.9, 27.3, and $27.34 \mathrm{~kg} / \mathrm{m}^{3}$. Based on this definition, geostrophic transports were calculated in each section for the surface layer with TWC water (Table 2). Except for the southward small portion of transport on the coastal side, the most transport resulted from UWE05. The northward transport was $1.20 \mathrm{~Sv}\left(\mathrm{~S} \equiv 10^{6} \mathrm{~m}^{3} / \mathrm{s}\right)$ in section $\mathrm{B}\left(36.0^{\circ} \mathrm{N}\right)$. Northward transport increased to $2.11 \mathrm{~Sv}$ in section $\mathrm{C}$ $\left(36.6^{\circ} \mathrm{N}\right)$ and had a maximum value of $3.39 \mathrm{~Sv}$ in section 
Table 2. Volume transports of the geostrophic current and ADCP-measured current along four sections in the upper layer from the sea surface to the isopycnal surface of $26.9 \sigma_{\theta}$

\begin{tabular}{|c|c|c|c|c|}
\hline \multirow{2}{*}{ Section } & \multirow{2}{*}{ Method } & \multicolumn{3}{|c|}{ Transport $\left(\mathrm{Sv}=10^{6} \mathrm{~m}^{3} / \mathrm{s}\right)$} \\
\hline & & Northward & Southward & Net \\
\hline \multirow{2}{*}{$\mathrm{B}\left(36.0^{\circ} \mathrm{N}\right)$} & Geostrophic & 1.20 & -0.69 & 0.51 \\
\hline & $\mathrm{ADCP}$ & 0.87 & -2.33 & -1.46 \\
\hline \multirow{2}{*}{$\mathrm{C}\left(36.5^{\circ} \mathrm{N}\right)$} & Geostrophic & 2.11 & -1.72 & 0.39 \\
\hline & $\mathrm{ADCP}$ & 2.19 & -1.49 & 0.70 \\
\hline \multirow{2}{*}{$\mathrm{D}\left(37.0^{\circ} \mathrm{N}\right)$} & Geostrophic & 3.39 & -2.48 & 0.91 \\
\hline & $\mathrm{ADCP}$ & 5.02 & -5.31 & -0.29 \\
\hline \multirow{3}{*}{$\mathrm{E}\left(37.5^{\circ} \mathrm{N}\right)$} & Geostrophic & 1.23 & -1.03 & 0.20 \\
\hline & ADCP & 0.57 & -1.55 & -0.98 \\
\hline & & Eastward & Westward & Net \\
\hline $\mathrm{SN}\left(131^{\circ} \mathrm{E}\right)$ & Geostrophic & 2.32 & -2.58 & 0.26 \\
\hline
\end{tabular}

$\mathrm{C}\left(37.0^{\circ} \mathrm{N}\right)$; it then decreased to $1.23 \mathrm{~Sv}$ in section $\mathrm{E}$ $\left(37.5^{\circ} \mathrm{N}\right)$. This indicates that the northward EKWC was maximized by the addition of recirculating water when it passed the central latitude of UWE05. On the other side, the southward transport was $1.03 \mathrm{~Sv}$ in section E, had a maximum of $2.48 \mathrm{~Sv}$ in section $\mathrm{D}$ at the central latitude of UWE05, and then decreased to $1.72 \mathrm{~Sv}$ in section $\mathrm{C}$ and to $0.69 \mathrm{~Sv}$ in section $\mathrm{B}$. This southward transport change seems to have resulted from the meandering of the EKWC around UWE05. In the section of the central longitude $\left(131^{\circ} \mathrm{E}\right)$ of the UWE05, the westward transport $(2.58 \mathrm{~Sv})$ was similar to the eastward transport $(2.32 \mathrm{~Sv})$. The ADCP-measured transport in the surface layer with TWC water was 5.02 Sv for northward transport and 5.31 Sv for southward transport. The large difference between the measured transport and geostrophic transport was because the distances between stations were too great to calculate the detailed eddy current structure. Furthermore, the geostrophic current was smoothed and averaged between stations. Therefore, it seems that the geostrophic transport in the eddy was underestimated compared with the measured transport.

For comparison of measured and calculated velocity profiles, Fig. 11 presents vertical profiles of meridional velocity. The measured velocity profiles were prepared by averaging all available data used for calculation of the geostrophic current between stations. Vertical shears were similar between measured and calculated velocities. In general, however, the measured current speeds were larger than the geostrophic current. In particular, a difference of more than $20 \mathrm{~cm} / \mathrm{s}$ in the surface layer was found in the

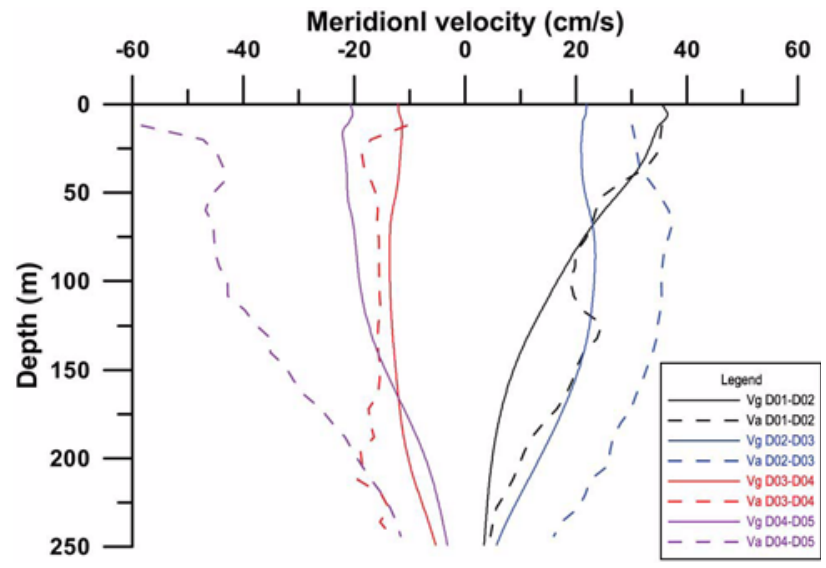

Fig. 11. Vertical profiles of meridional velocity measured by the ship-mounted ADCP (Va: dotted lines) and calculated dynamically (Vg: solid lines) between station pairs along $37.0^{\circ} \mathrm{N}$. Va profiles were compiled from averages of all data between stations.

eastern part of the eddy (stations D04 and D05). Thus, the measured transport was larger than the geostrophic current.

Fig. 12 shows the geostrophic transport and its direction for every station pair in the upper layer over the dynamic topography at $50 \mathrm{db}$. The upper layer in this case is the surface water and the TWC water, i.e., from the sea surface to isopycnal surface of $26.9 \sigma_{\theta}$.

Mass conservation of geostrophic transport was satisfied in eight of the 15 closed boxes within order of magnitude of -1 . The remaining seven boxes had errors of $\pm 0.1 \mathrm{~Sv}$. This means that UWE05 was well developed in terms of geostrophic balance. Takikawa et al. (2005) reported that average absolute transport was $1.54 \mathrm{~Sv}$ through the western channel of the Korea Strait. Here, relative transport northward to northeastward was calculated as $1.4 \mathrm{~Sv}$ around the southwestern part of UWE05. The transport supplied $1 \mathrm{~Sv}$ to the south of UWE05, and $1 \mathrm{~Sv}$ flowed out from the south and southeast portions of the eddy. Therefore, not all EKWC water transported from the Korea Strait circulated around the eddy or was added again to the eddy. It seems that a similar amount of transport flowed out from the eddy as was supplied to the eddy from the EKWC. In other words, the EKWC meandered around UWE05 and was mixed with water surrounding the eddy. In the central latitude $\left(37.0^{\circ} \mathrm{N}\right)$ of UWE05, northward transport (3.4 Sv) and southward transport $(3.5 \mathrm{~Sv})$ were nearly equal. However, westward transport $(2.5 \mathrm{~Sv})$ was slightly larger than eastward transport $(2.3 \mathrm{~Sv})$ in the $131.0^{\circ} \mathrm{E}$ section, likely because of the limited number of observation stations to the north of UWE05. 


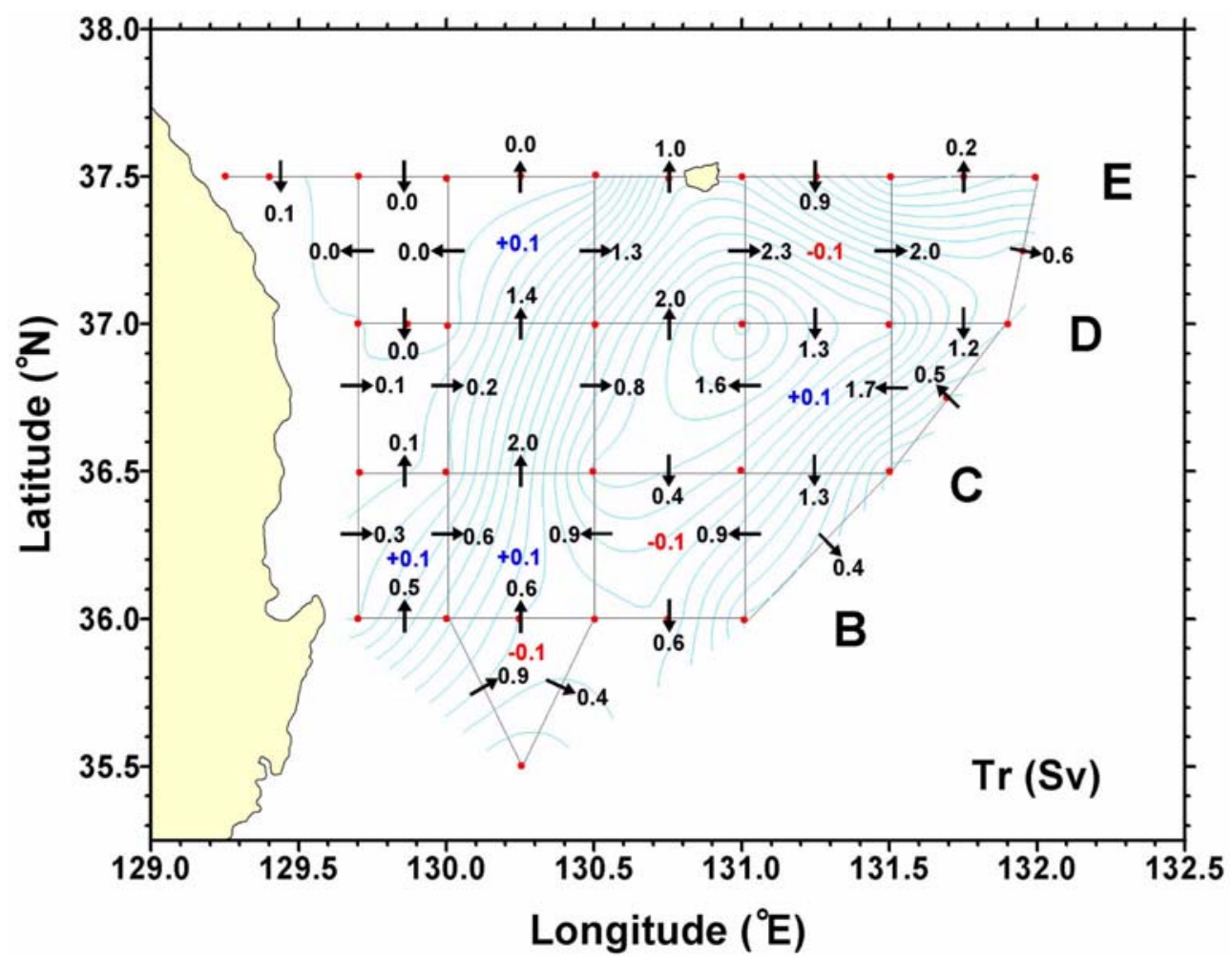

Fig. 12. Geostrophic volume transports $\left(S v \equiv 10^{6} \mathrm{~m}^{3} \mathrm{~s}^{-1}\right)$ between stations in a layer from the sea surface to an isopycnal surface of $\sigma_{\theta}=26.9$ over the dynamic height (light blue) at a depth of $50 \mathrm{db}$. Arrows and numbers indicate the directions and quantities of transport, respectively. Mass balance was satisfied in eight of the 15 closed boxes within an order of magnitude of -1 . Errors of the remaining boxes were $+0.1 \mathrm{~Sv}$ (blue numbers) in four boxes and $-0.1 \mathrm{~Sv}$ (red numbers) in three boxes.

\section{Conclusion and discussion}

To understand the characteristics of a warm eddy that formed in the Ulleung Basin, oceanographic data observed in July 2005 were analyzed. The horizontal distribution of temperature at $200 \mathrm{db}$ revealed an area of water warmer than surrounding water in the Ulleung Basin. The traverse temperature section revealed a homogeneous layer between the seasonal and permanent thermocline, providing evidence of a mesoscale warm eddy in the Ulleung Basin (UWE05) at that time. The dynamic topography and surface currents also clearly demonstrated the existence of UWE05, rotating in an anticyclonic direction in the Ulleung Basin. Based on the $5^{\circ} \mathrm{C}$ isothermal line on $200 \mathrm{db}$ temperature, the major axis was $160 \mathrm{~km}$ from southwest to northeast, and the minor axis was 80 from southeast to northwest.

At station D03 at the center of UWE05, the minimum Brunt-Väisälä frequency was found in the homogeneous layer. This layer had mean values of $10.40^{\circ} \mathrm{C}$ potential temperature, $34.35 \mathrm{psu}$ salinity, and $26.37 \mathrm{~kg} / \mathrm{m}^{3}$ potential density $\left(\sigma_{\theta}\right)$. The existence of this homogeneous layer suggests that UWE05 existed over winter 2004-2005. This was further proved by analyzing NFRDI data, which indicated that the homogeneous layer was also formed during that winter and had different temperature and salinity. A warm streamer initially flowed along the circumference of UWE05 and mixed with the upper central water of UWE05. Thus, the high salinity water over the homogeneous layer came from the warm streamer.

Two northward current cores were shown in the western side of the measured current section at the central latitude of UWE05. One was the EKWC on the Korean coast side, and the other was the western part of UWE05. Geostrophic transport of the upper layer (from the surface to isopycnal surface of $26.9 \sigma_{\theta}$ ) of UWE05 was approximately $2.5 \mathrm{~Sv}$ at the eastern side of UWE05. However, measured transport was twice the value of geostrophic transport because the distances between the stations were too great for detailed calculation of the eddy.

Mass conservation of geostrophic transport was well satisfied in the upper layer. North to northeast transport 
was calculated as $1.4 \mathrm{~Sv}$ in the southwestern part of UWE05. Analysis of the geostrophic transport revealed that the transport by the eddy was supplied from only part of the EKWC and that a similar amount of transport flowed out from the eddy. Not all of the transport that passed through the Korea Strait circulated around the eddy. Furthermore, not all of the southward transport of the eddy was added back to the eddy. This suggests that the EKWC was meandering around UWE05 and being mixed with water surrounding the eddy.

The geostrophic transport indicated that inflow to UWE05 from the EKWC was approximately $1 \mathrm{~Sv}$. In the ADCP measurement, the main transport of UWE05 was five times the geostrophic input transport in the upper layer. In this study, calculation of the measured transport budget was not possible in each box because the ship tracking was not in a lattice pattern. Furthermore, the geostrophic transport was not consistent with measured transport. Thus, to exactly calculate the transport of this type of eddy, a survey plan for direct current measurements is needed. Detailed surveys of temperature and salinity are also required to understand their detailed variations in the homogeneous layer of the Ulleung warm eddy. In this study, UWE05 was tracked from December 2004 to August 2005. To better understand the movements and lifetimes of this type of eddy, long-term observations and analyses of satellite data are also required.

\section{Acknowledgements}

The author would like to thank anonymous reviewers for their valuable comments. This study was supported by project PE98312 of the Korea Ocean Research and Development Institute (KORDI).

\section{References}

An H, Shim K, Shin H-R (1994) On the warm eddies in the southwestern part of the East Sea (the Japan Sea). J Korean Soc Oceanogr 29(2):152-163

Arruda WZ, Nof D, O'Brien JJ (2004) Does the Ulleung eddy owe its existence to $\beta$ and nonlinearities? Deep-Sea Res I 51(12):2073-2090. doi:10.1016/j.dsr.2004.07.014

Cho K-D, Bang T-J, Shim T-B, Yu H-S (1990) Three dimensional structure of the Ullung Warm Lens. Bull Korean Fish Soc 23(4):323-333

Gordon A, Giulivi CF, Lee CM, Furey HH, Bower A, Talley L (2002) Japan/East Sea intrathermocline eddies. J Phys Oceanogr 32(6):1960-1974. doi:10.1043/1520-0485(2002) 032(1960:JESIE)2.0.CO;2
Isoda Y, Saitoh S (1993) The northward intruding eddy along the east coast of Korea. J Oceanogr 49(3):443-458

Jacobs GA, Hogan PJ, Whitmer KR (1999) Effect of eddy variability on the circulation of the Japan/East Sea. J Oceanogr 55(2):247-259

Kang J-H, Kim W-S, Chang K-I, Noh J-H (2004) Distribution of plankton related to the mesoscale physical structure within the surface mixed layer in the southwestern East Sea, Korea. J Plankton Res 26(12):1515-1528. doi:10.1093/plankt/fbh140

Kang H-E, Kang YQ (1990) Spatio-temporal characteristics of the Ullung Warm Lens. Bull Korean Fish Soc 23(5):407-415

Kim SY, Lee J-C, Lee H-S, Shim TB (1997) Numerical experiment on the Ulleung Eddy due to the variation of the Tsushima Current in the East Sea. J Korean Fish Soc 30(6): 1033-1043

Lee DK, Niiler PP (2005) The energetic surface circulation patterns of the Japan/East Sea. Deep-Sea Res II 52(1113):1547-1563. doi:10.1016/j.dsr2.2003.08.008

Lie H-J, Byun S-K, Bang I, Cho CH (1995) Physical structure of eddies in the southwestern East Sea. J Korean Soc Oceanogr 30(3):170-183

Lim K-S, Kim K (1995) A numerical study on the interaction of Ulleung Warm Eddy with topography and lateral boundary. J Korean Soc Oceanogr, 30(6):565-583

Morimoto A, Yanagi T, Kaneko A (2000) Eddy field in the Japan Sea derived from satellite altimetric data. J Oceanogr 56(4):449-462. doi:10.1023/A:1011184523983

Shin C-W, Byun S-K, Kim C (1996) Comparison between geostrophic currents and measured currents in the southwestern part of the East Sea. J Korean Soc Oceanogr 31(2):89-96

Shin C-W, Byun S-K, Kim C, Seung YH, Lee JH (1999) Circulation in the southwestern East Sea (Japan Sea) determined by an inverse method in July 1993. Ocean Res 21(2):87-97

Shin H-R, Shin C-W, Kim C, Byun S-K, Hwang S-C (2005) Movement and structural variation of warm eddy WE92 for three years in the Western East/Japan Sea. Deep-Sea Res II 52(11-13):1742-1762. doi:10.1016/ j.dsr2.2004.10.004

Seung YH (2002) A simple analytical model for the interaction between the East Korean Warm Current and the Ulleung Warm Eddy. J Korean Soc Oceanogr 37(1):20-26

Seung YH, Nam SY, Lee SY (1990) A combined effect of differential cooling and topography on the formation of Ulleung Warm Eddy. Bull Korean Fish Soc 22(6):375-384

Takikawa T, Yoon J-H, Cho K-D (2004) The Tsushima Warm Current through Tsushima Straits estimated from ferryboat ADCP data. J Phys Oceanogr 35(6):1154-1168. doi: 10.1175/JPO2742.1

Received Jan. 31, 2009

Revised Sep. 2, 2009

Accepted Nov. 11, 2009 